Muhammad Majid Khan, Associate Professor, Management Sciences Department, COMSATS University, Islamabad, Pakistan

Bahaudin G. Mujtaba, Professor, Nova Southeastern University, Florida, USA

\title{
THE IMPACT OF PROJECT MANAGERS' COMPETENCIES, EMOTIONAL INTELLIGENCE AND TRANSFORMATIONAL LEADERSHIP ON PROJECT SUCCESS IN THE INFORMATION TECHNOLOGY SECTOR
}

The study aims to examine the impact of project managers' competencies (PMC), emotional intelligence (EQ) and transformational leadership (TL) on project success (PS). Data were collected from 250 respondents including project managers, project leaders, project directors, functional managers, and project sponsor board members working in the information technology (IT) sector. The results of the analysis revealed that the project manager's prominent characteristics influence the success of the project positively. The study proposes the hiring of project managers, project leaders, and project directors who have competencies like communication, teamwork, attentiveness and conflict management along with expertise in managerial skills in the IT sector. Moreover, resources must be made available to train the existing workforce and enhance their competencies, emotional intelligence and transformational leadership styles through professional courses, workshops and seminars. This study supports the theoretical argument that a project manager with a transformational leadership style has a positive impact on the project's success. IT project managers ranked transformational leadership as an important aspect for project success. Transformational leaders are inspiring and encouraging, stick to their teams, motivate employees, show them a correct path, and boost employees' confidence. As a result, a responsive and pleasant environment will be created in which the whole team works together under a trustworthy project manager and attain the project goals. The research provides a unique set of lessons that organizations can use to design or re-design their activities in order to improve the efficiency of their employees.

Keywords: competencies, emotional intelligence, transformational leadership, project success.

Introduction. While every industry is susceptible to projects failure, the technology business is known to be a reason for risk, failure and competition more than the various other fields (Whitney \& Daniels, 2013). Papke-Shields, Beise and Quan (2010) surveyed 600 associations in 22 nations and found that project outcomes of $86 \%$ respondents fell short of planned expectations; thus, there is a growing concern about the factors that influence project success.

Projects are often criticized for their delays, budget deviances, low productivity, and low product quality. An unsuccessful project can bring about calamities to project stakeholders (Maqbool, Sudong, Manzoor, and Rashid, 2017). In projects, misfortune, uncertainty and doubtfulness are continually present 
to test the patience of project managers. Manager and human resources professionals must proceed cautiously and ethically as they assess and evaluate the success of project managers for complex and stressful projects (Mujtaba, Tajaddini. and Chen, 2011; Mujtaba and Sims, 2011; Shoaib and Mujtaba, 2017). All professionals must always balance the challenges of reckoning out what to do with the enactment of their projects, in spite of uncertainty, great variety and a huge amount of potentially relevant information (Tajaddini and Mujtaba, 2011; Ping, Mujtaba and Jieqiong, 2012; Pelletier \& Mujtaba, 2015). So, the project managers play the most life-threatening part towards the accomplishment of any project (Yang, Huang, \& Wu, 2011a).

According to Mabelo (2011), project managers who lack certain critical competencies are a "common cause of project failure". The project manager requires additional competencies and comprehensive management skills (Hauptfleisch \& Uys, 2006). Present era writers have documented the lenient competencies in place of central aspects of being successful in any venture (Shi, 2006). Davis (2014) is of the opinion that there is a range of components that play critical roles in the success of ventures, comprising the practical proficiency of project teams, communication skills, and project managers.

A project manager/leader should have an idea of people's demands and needs and should be able to fulfil them in a timely manner. A project manager/leader must apprehend what drives people and must be able to procure their self-interest in search of the project's goals and objectives. Project managers with higher levels of emotional intelligence tend to use open communication (projects manager's competency) and progressive leadership styles (Transformational Leadership). According to Sunindijo, Hadikusumo, and Ogunlana (2007), emotional intelligence provokes open communication, proactive behaviour and trust, which brings positive consequences to the organization. The emotional attributes of project managers help teams to link their particular knowledge and skills together to make sure that the project is effectively accomplished within budget and time requirements (Rebecca Turner \& Lloyd-Walker, 2008).

All projects in different sectors are unique in nature and cover risks across many issues throughout the processes. One of the sectors that is blooming and rising sector of all developing economies is the Information Technology (IT) sector. The nature of work in the IT sector is mostly project based. The failure of IT projects continues to trouble managers and organizations (Sumner, Bock, \& Giamartino, 2006).

The IT environment is demanding, perplexing and vigorous. Likewise, IT project managers handle technical employees, leaders, users, work breakdowns, and miscommunications (Sumner et al., 2006). In order to be successful, IT project managers have to improve their project management competencies and skills. Although the literature highlights the association amongst the Project Managers' Competencies (PMC), Emotional Intelligence (EQ), Transformational Leadership (TL) and the likely project success, yet an in-depth empirical analysis needs to be carried out.

Literature Review. A project manager's major concern, as a leader, is to achieve the project objectives. This can be achieved by concentrating on both the sensible and emotional elements of a project using an assimilated methodology. Studies have discovered that the project manager's role is vital to project success; however, literature has largely overlooked the effects of project manager's competencies (PMC), emotional intelligence (EI) and leadership tactics (Transformational leadership) on project success (Turner \& Müller, 2005; Avolio \& Yammarino, 2013). Three theories were related to the variables like project manager competencies, emotional intelligence and transformational leadership, and these are competence school, emotional intelligence school and visionary leadership school respectively.

In order to carry out a thorough study on the impact of these factors on project success, the subsequent section will create the relevant hypotheses.

Project Manager's Competencies and Project Success. The project manager is considered as one of the main persons who have a greater contribution in driving a project toward successful achievement (Gladden, 2007). Salajeghe (2014) defined the term competence assets of activities that includes the skills, knowledge, abilities and personal characteristics that are necessary for successful role 
A. Afzal, M.M.Khan, B. G. Mujtaba. The Impact of Project Managers' Competencies, Emotional Intelligence and Transformational Leadership on Project Success in the Information Technology Sector

accomplishment. The Project Management Competency Development (PMCD) Framework explains a project manager's competency as the process by which the project manager endlessly applies his/her knowledge, skills and personal behaviours with the purpose of delivering projects that will meet the requirements of the different stakeholders (Cartwright \& Yinger, 2007). For instance, the skills and competencies are key for active communication with team members and conflict resolution. Secondly, the knowledge competencies recognized as professional practice gap of the learner can be based on a range of needs. Thirdly, experience competencies mean that the project manager uses information from a variety of sources-including personal experience and his/her own observations-to identify options and solve problems.

In project management, project managers' competencies are found to be central to their success (Brown \& Eisenhardt, 1995; Crawford, 2005; Geoghegan \& Dulewicz, 2008; Katz \& Allen, 1985). Ekrot, Kock and Gemünden (2016) identified that Project Management Competence Retention (PMCR) is positively connected with the project success rate of an organization. Researchers like Brière, Proulx, Flores, and Laporte (2015) discovered that project manager skills are exceptionally focal amid pivotal project changes and these are critical for venture administration abilities.

Hauschildt, Keim and Medcof (2000) present the various types of project managers and its linkage to project success. Between these studies, quite a few show more precisely the importance of human skills (Alam, Gale, Brown, \& Khan, 2010b; Clarke, 2010a; El-Sabaa, 2000; Henderson, 2008; Pant \& Baroudi, 2008) and soft skills (Gillard \& Price, 2005; Leybourne \& Sadler-Smith, 2006; Muzio, Fisher, Thomas, \& Peters, 2007; Neuhauser, 2007; Skulmoski \& Hartman, 2010; Stevenson \& Starkweather, 2010; Mujtaba, 2014).

Thus, we can hypothesize that:

H1: Project manager's competencies are positively related to project success.

Emotional Intelligence and Project Success. Human factors are of vital importance to the success of projects. Though many studies have focused on human factors of project management, not much research has been done on emotional intelligence (EQ). Studies have shown that $E Q$ is advantageous to both the individual and the organization.

The concept of EQ raises (Taine, 1871) estimation of mutual human capabilities and the need to measure an individual's intellectual qualities to provide a theoretical understanding of human capabilities. Researchers (Wong \& Law, 2002) (Mayer, Caruso, \& Salovey, 1999) have explained EQ as a set of interconnected skills to distinguish accurately, assess, and express emotion; it is the ability to access and/or generate feelings as they can aid thought; it is the ability to understand emotional knowledge; and it is the ability to control emotions to endorse emotional as well as intellectual growth. The concept of EQ has attracted massive amounts of thoughtfulness from researchers and scholars (Andrei, Smith, Surcinelli, Baldaro, \& Saklofske, 2016; Ashkanasy, Haertel, \& Zerbe, 2000; Goleman, Hartel, Boyatzis, \& Mckee, 2002; Miao, Humphrey, \& Qian, 2016, 2017).

Emotional intelligence plays a vital role in the success of any project. Goleman (1995) as well as Goleman, Boyatzis, and McKee (2002) identified that emotional intelligence (EQ) is twice as much more important than technical skills and intelligence quotient for jobs at all levels. EQ plays gradually more important role at the highest levels of an organization. It appears that EQ identifies to a number of nonintellectual abilities, aptitudes, or competencies that impact a manager's ability to manage pressures and environmental demands.

Researchers (Pryke, Lunic, \& Badi, 2015; Rehman, 2011; Sunindijo, Hadikusumo, \& Ogunlana, 2007) have concluded that emotional intelligence is valuable in a leader-devotee correspondence as it prompts project execution. Rezvani et al. (2016) found a significant relationship between project managers' emotional intelligence and project success with the mediating role of job satisfaction and trust in the Australian Defense industry. According to Sunindijo (2015), emotional intelligence has a considerable 
effect on project quality performance and project cost performance.

Hence we can put forward that:

$\mathrm{H} 2$ : Project manager's emotional intelligence is positively related to project success.

Transformational leadership and Project Success. Leadership is a concept that has often been found to correspond with emotional intelligence (Ashkanasy \& Tse, 2000). Management of emotions in oneself and in others is a vital component of leadership. In literature, there are different schools of leadership theory, in which transformational leadership can be found amid the modern perspectives (Keegan, 2004; Turner \& Müller, 2005). Burns (1978) is considered as the predecessor of the transformational theory of leadership and observed transformational leadership as a prerequisite to attain and successfully manage change within constantly varying world conditions.

According to Pieterse, van Knippenberg, Schippers, and Stam (2010), transformational leadership is a way to deal with followers to make them look past self-centeredness in favour of the group's objectives by adjusting their morale, ideals and values. It is linked with motivating and inspiring groups to bring extraordinary results while increasing their own leadership abilities (Bass \& Riggio, 2006).

To attain managerial and administrative goals the leaders' style is predominantly very important (Zareen, Razzaq and Mujtaba, 2015). Researchers (Awamleh, Gardner, \& Gardner, 1987; Conger, 1999; Dubinsky, Yammarino, Jolson, \& Spangler, 1995; Yammarino, Spangler, \& Bass, 1993) constantly signify the worth of transformational leadership style over transactional leadership style, in provisions of accomplishing organizational targets.

Research on different leadership styles shows that transformational leadership is more powerful than transactional and laissez-faire leadership styles (Gardner \& Stough, 2002; Zareen, Razzaq and Mujtaba, 2015). According to Lowe, Kroeck and Sivasubramaniam (1996), transformational leaders are frequently considered as helpful by their subordinates and are associated with higher administrative and managerial performance and success. Transformational leadership has been viewed as a vital individual factor that supports advancement and execution in the work environment (Keegan \& Hartog, 2004; Yang et al., 2011a).

Manager's transformational leadership (TL) attitude has been found to have a positive and significant relationship with project performance (Kissi, Dainty, \& Tuuli, 2013). Researchers (Gundersen, Hellesoy, \& Raeder, 2012) have shown that TL has a high level of significance for project-oriented organizations. According to Sy, Côté and Saavedra (2005), the usage of positive move can also impact followers' mood states, which in turn have an impact on project outcomes. Researchers (Aga, Noorderhaven, \& Vallejo, 2016a) have observed that for project success, team building is considered vital as it plays a mediating role in the relationship between transformational leadership and project success.

Transformational leaders, therefore, inspire followers to perform beyond their expectations as individuals and teams. According to Sohmen (2013), these transformational leaders also nurture strong relationships. Transformational-style project managers improve mutual understanding and group consistency, aid the open discussion of ideas and logical perception through project teams, and highlight the development of follower self-management or self-leadership skills. As a result, transformational leaders can generate an atmosphere where team members put forth continuous effort for project success (Burke et al., 2006).

Therefore, we can hypothesize that:

H3: Project manager's transformational leadership is positively related to project success.

Research Model and Methodology. On the basis of literature review, four variables have been conceptualized including PMCs', EQ, TL and PS. The present research is about the impact of the project manager's competencies, emotional intelligence and transformational leadership on project success. 
A. Afzal, M. M. Khan, B. G. Mujtaba. The Impact of Project Managers' Competencies, Emotional Intelligence and Transformational Leadership on Project Success in the Information Technology Sector

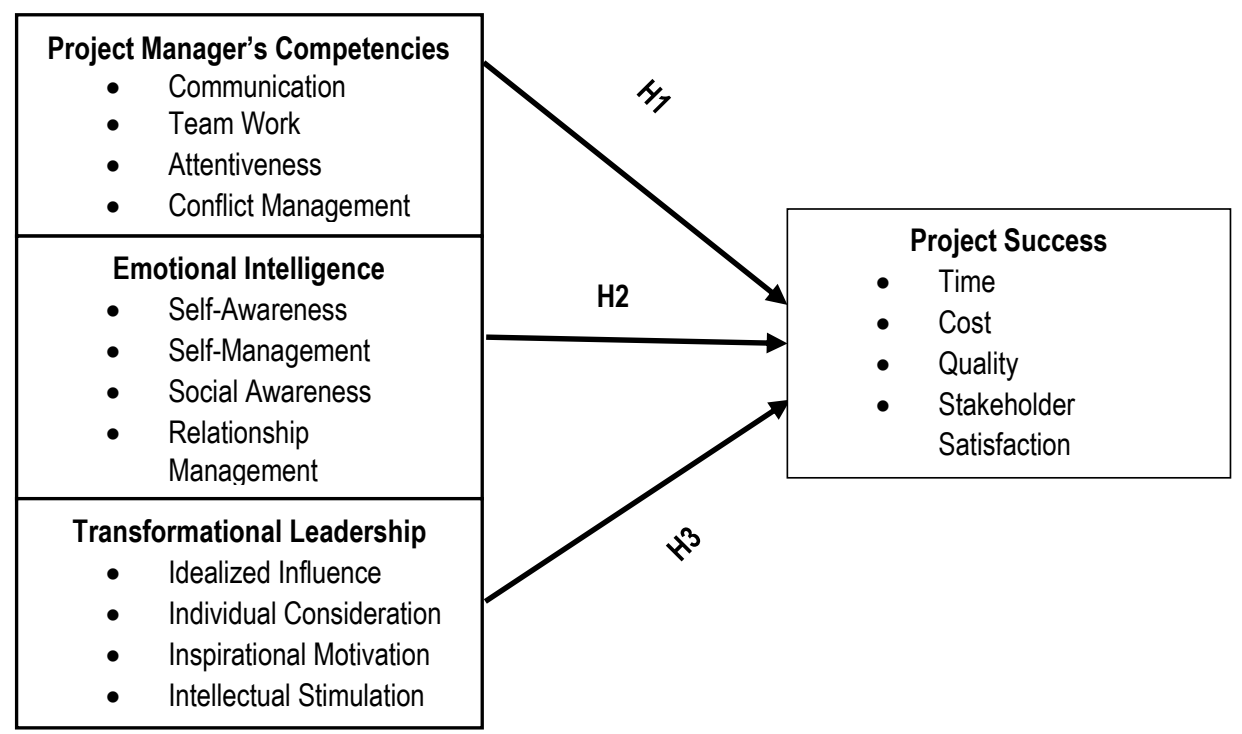

Figure 1 - Project Success Framework

This study is quantitative with project managers working in the information technology sector of Rawalpindi/lslamabad. Data were collected from both male and female project managers. The time horizon of this study was cross-sectional and the study setting is non-contrived (Vinhas Da Silva \& Faridah Syed Alwi, 2006).

Primary data of this study has been collected by using a structured questionnaire. The questionnaire was adopted from the researcher's base study (Maqbool et al., 2017) which was conducted in the construction sector. The instrument contains two parts, one is the demographic part; while the other part measures variables such as project manager's competencies, emotional intelligence, transformational leadership and project success. Seven point Likert scales (Interval Scale) is used to collect the responses. The Likert scale contains 1-Strongly agree, 2-Agree, 3-More or less agree, 4-Undecided, 5- More or less disagree and 6-Disagree, 7-Strongly disagree. The questionnaire is in the English language, which is one of the official languages for everyone in the country.

Sampling. The technique used for data collection was convenience sampling. Convenience technique comprises of respondents that are voluntarily accessible and agree to take part in a study (Fink, 1995; Frey et al., 2000; Henry, 2009; MacNealy, 1999).

The project management community members serving in leadership roles in the information technology sector forms the population of this study. This community includes Project Directors, Project Managers, Project Team Leaders, Functional Managers and Project Sponsor Board Members. For this particular study, the software houses of Rawalpindi/lslamabad (MTBC, S \& P Global, Teradata, Ufone, LMKT, DPN, 360 Technologies, and NetSol) is the population. The main reason for selecting software houses was that the Information Technology sector is growing rapidly in Pakistan. According to Pakistan Software Export Board (2016), about $\$ 2.2$ billion of Pakistan's economy are from the IT sector.

Analysis and Techniques. The study is quantitative in nature and has a causal relationship. To examine the data correlation, normality and regression tests have been done. Descriptive data analysis techniques were applied to the collected data that includes meaning, median, mode, and standard deviation in order to present the mean characteristics of the sample. In this study, Correlation and Multiple Linear Regression analysis techniques were used for analyzing the association between the independent 
and dependent variables.

Results. Descriptive statistics show the values of the mean as well as standard deviation. All variables were assessed on a 7-point Likert scale.

Table 1 shows that the mean value of project success, project manager competencies, emotional intelligence, and transformational leadership was 1.9, 2.05, 2.19 and 1.82 respectively. Highest mean was of "Project Success" ( $M=1.9)$, while lowest mean was of "Emotional Intelligence" $(M=2.19)$. Standard Deviation for Project Success is .57, Project Manager Competencies is .46, Emotional Intelligence is .55 and Transformational Leadership is .54.

Table 1 - Descriptive Statistics

\begin{tabular}{|c|c|c|c|c|c|}
\hline & $\mathrm{N}$ & Mean & Std. Deviation & \multicolumn{2}{c|}{ Skewness } \\
\cline { 2 - 6 } & Statistic & Statistic & Statistic & Statistic & Std. Error \\
\hline Pro_Suc & 250 & 1.9631 & .57771 & 1.798 & .154 \\
\hline PMC & 250 & 2.0557 & .46917 & .585 & .154 \\
\hline EMO_INT & 250 & 2.1958 & .55445 & .298 & .154 \\
\hline TL & 250 & 1.8210 & .54118 & .721 & .154 \\
\hline Valid N (listwise) & 250 & & & & \\
\hline
\end{tabular}

From table 2 we can see that the greatest correlation is in between Project manager competencies (PMC) and Project Success (PS) i.e. 0.699. Then Emotional intelligence (EMO_INT) and Project Success (PS) i.e. 0.633. And Lastly Transformational leadership (TL) and Project Success (PS) i.e. 0.594. The primary finding is that all correlations are positive.

The coefficient of determination in statistics is symbolized as $r^{2}$ or $R^{2}$ and generally it, is pronounced by $R$ square. It is mainly a single digit which classifies how exactly the data best fits the specific statistical model. It is just a curve or single line that characterizes the entire phenomena. If the value turns out to be $0 \%$ it portrays that no single response in data's changeability has been recognized about meanthe. The $\mathrm{R}$ square value provided by regression in table 3 is 0.587 . $R$ square value directs that 3 independent variables are conveying $58.7 \%$ changes in the dependent variable. The research results by Magbool et al. (2017) show that depethe ndent variable is changed by the independent variable with $52.4 \%$. By comparing the above results, we can say that present research is more significant.

Table 2 - Correlations

\begin{tabular}{|c|c|c|c|c|c|}
\hline & Pro_SuC & PMC & EMO_INT & TL \\
\hline Pro_Suc & Pearson Correlation & 1 & & & \\
\hline PMC & Pearson Correlation & $0.699^{* *}$ & 1 & & \\
\hline EMO_INT & Pearson Correlation & $0.633^{* *}$ & $0.740^{* *}$ & 1 & \\
\hline TL & Pearson Correlation & $0.594^{* *}$ & $0.514^{* *}$ & $0.554^{* *}$ & 1 \\
\hline \multicolumn{7}{|c|}{} & ${ }^{* *}$. Correlation is significant at the 0.01 level (2-tailed). \\
\hline
\end{tabular}

After running the ANOVA or the regression analysis we obtained results of $F$ Statistics. The results depict that either the group of independent variables are mutually significant or not. The variance test ( $p$ value) remains below the range of 0.05 will depicts the goodness of fit and significance as well.

We can see from table 4 that significance is 0.00 . As the value is below the range of 0.05 , this significance clearly confirms that the set of independent variables in the perspective of the joint venture is significant. The analysis shows that the calculated value of the F-Statistics for the present research model is 37.830 , this connotes that the variables are statistically and mutually significant in the model. 
A. Afzal, M. M. Khan, B. G. Mujtaba. The Impact of Project Managers' Competencies, Emotional Intelligence and Transformational Leadership on Project Success in the Information Technology Sector

Table 3 - Model Summary

\begin{tabular}{|c|c|c|c|c|c|c|c|c|c|}
\hline \multirow[b]{2}{*}{ Model } & \multirow[b]{2}{*}{$\mathrm{R}$} & \multirow[b]{2}{*}{$\begin{array}{c}\mathrm{R} \\
\text { Square }\end{array}$} & \multirow[b]{2}{*}{$\begin{array}{c}\text { Adjusted R } \\
\text { Square }\end{array}$} & \multirow{2}{*}{$\begin{array}{c}\text { Std. The error } \\
\text { of the } \\
\text { Estimate }\end{array}$} & \multicolumn{5}{|c|}{ Change Statistics } \\
\hline & & & & & \begin{tabular}{|l|} 
R Square \\
Change
\end{tabular} & F Change & $\mathrm{df1}$ & $\mathrm{df}$ & $\begin{array}{l}\text { Sig. F } \\
\text { Change }\end{array}$ \\
\hline 1 & $.259 a$ & .067 & .044 & .56490 & .067 & 2.903 & 6 & 243 & .009 \\
\hline 2 & $.766^{b}$ & .587 & .571 & .37838 & .520 & 100.546 & 3 & 240 & .000 \\
\hline \multicolumn{10}{|c|}{ a. Predictors: (Constant), Job Location, Qualification, Gender, Designation, Age Group, Experience } \\
\hline \multicolumn{10}{|c|}{$\begin{array}{l}\text { b. Predictors: (Constant), Job Location, Qualification, Gender, Designation, Age Group, Experience, PMC, TL, } \\
\text { EMO_INT }\end{array}$} \\
\hline
\end{tabular}

PMC's beta coefficient is significant at 0.000 level in table 5 . The estimation of the beta coefficient is 0.458 which implies that keeping the rest of the factors consistent, if we bring one unit change in the PMC, the dependent variable (PS), will be changed by 0.458 Maqbool et al. (2017) also found positive relation between Project Manager's Competencies and Project Success. So as a result, we cannot reject the hypothesis (H1) that Project Manager's Competencies positively influences the Project Success.

Table 4 - ANOVA ${ }^{a}$

\begin{tabular}{|c|c|c|c|c|c|c|}
\hline \multicolumn{2}{|c|}{ Model } & Sum of Squares & $\mathrm{df}$ & Mean Square & $\mathrm{F}$ & Sig. \\
\hline \multirow{3}{*}{1} & Regression & 48.744 & 9 & 5.416 & 37.830 & $0.000^{\circ}$ \\
\hline & Residual & 34.360 & 240 & 0.143 & & \\
\hline & Total & 83.104 & 249 & & & \\
\hline
\end{tabular}

Also, for the second independent variable, table 5 indicates that emotional intelligence (EMO_INT) is significant at the level of 0.038 ; however, the value of the beta coefficient is 0.138 . This signifies that keeping the rest of the factors consistent, if we bring one unit change in the EMO_INT, the dependent variable (PS) will be changed by 0.138 .

Table 5- Coefficients

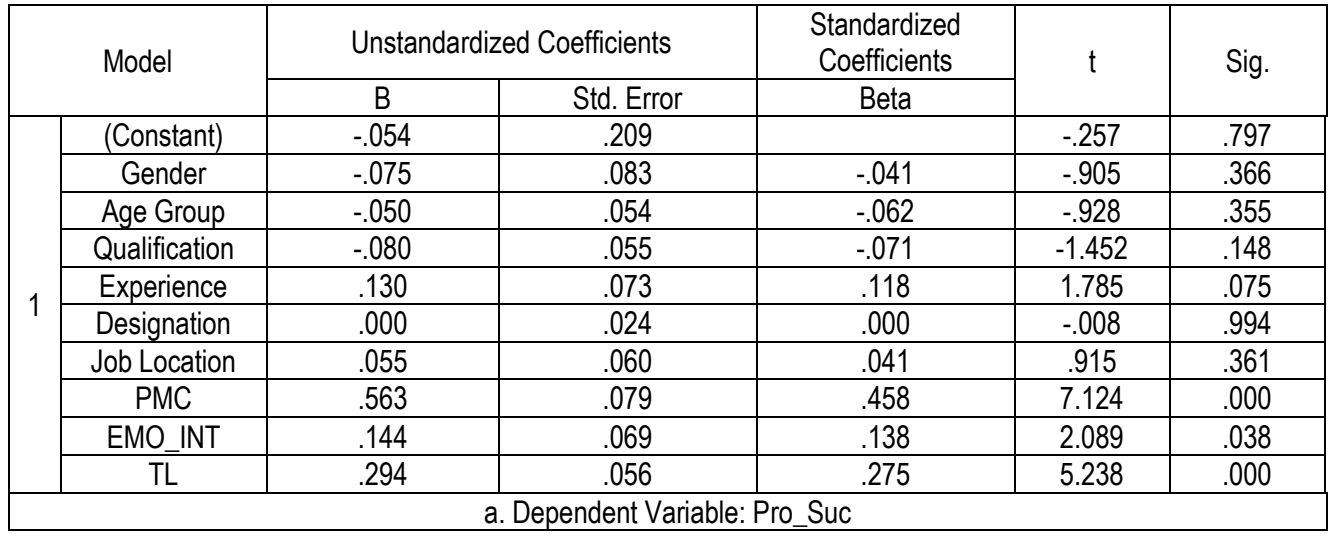

Maqbool et al. (2017) also found a positive relationship between emotional intelligence and project success. So as a result, we cannot reject the hypothesis $(\mathrm{H} 2)$ that Emotional Intelligence positively influences the Project Success. 
The last independent variable indicates that Transformational Leadership (TL) is significant at the level of 0.00 , however, the value of the beta coefficient is 0.275 . This signifies that keeping the rest of the variables constant, if we bring one unit change in the $T L$, the dependent variable (PS) will be changed by 0.275. Maqbool et al. (2017) also found positive relations between Transformational Leadership and Project Success. So as a result, we cannot reject the hypothesis $(\mathrm{H} 3)$ that Transformational Leadership positively influences the Project Success.

Discussion. To scrutinize the roles of $P M C, E Q$, and $T L$ in enhancing venture performance was the significant motivation behind this research work. The results exhibit critical constructive connections of independent variables (PMC, EQ and TL) with a dependent variable (PS). We can see that $P M C, E Q$, and TL have a positive impact on the project's success.

Previous studies concentrated on the administrative and technical skills of project managers' but later on they took soft skills more into consideration. Nowadays a project manager who has the ability to talk, convince and motivate other people, ability to understand problems, ability to produce a new product, ability to manage a huge team or large project, ability to utilize software, and have technical expertise is likely to remain successful.

Project success was significantly linked to the project managers' capabilities. The one-unit change in the beta value of 0.458 shows that PMC has $45.8 \%$ impact on PS. So, hypothesis 1 was supported. This is related to previous studies (i.e. Malinowski, 2012) who found that a project manager 's leadership competencies can significantly and positively affect the project's success as well as organizational success. Other researchers (Maqbool et al., 2017; Müller \& Rodney Turner, 2010) have also found positive and encouraging relationships between PMC's and PS. Most researchers (Clarke, 2010b; Creasy \& Anantatmula, 2013) agree that project managers with a collection of fundamental capabilities are critically important to the accomplishment of new ventures.

Project success was likewise positively linked with emotional intelligence. The one-unit change in the beta value of 0.138 shows project managers' emotional intelligence has $13.8 \%$ impact on a project's success. So hypothesis 2 was supported. According to Davis (2011), project managers with high EQ were able to strategize their approach to handle different problems and to overcome new challenges that each project presented. Overall, similar to the results of our study, most previous researchers (Brackett, Rivers, \& Salovey, 2011; Clarke, 2010b; Müller \& Turner, 2010; Obradovic, Jovanovic, Petrovic, Mihic, \& Mitrovic, 2013; Rezvani et al., 2016) have shown that there is a significantly positive relationship between EQ and PS.

Finally, project success was found to positively correlate with transformational leadership. Similarly, studies in the past (Aga, Noorderhaven, \& Vallejo, 2016b) have illustrated that a project manager's leadership style has a vital role in the venture's success. Ultimately, transformational project managers inspire and motivate their team, leading them towards the ideal plan for project success, categorized by effectiveness, stakeholder satisfaction and efficiency. Other researchers (Anantatmula, 2010; Jiang, 2014; Kissi et al., 2013; Vincent-Höper, Muser, \& Janneck, 2012; Yang et al., 2011b) also show that there is a significant positive relationship between transformational leadership and project success.

Implications and Limitations. The outcomes of this study led us to report a strong understanding of the linkage between PMC's, EQ and TL with PS. While the organizational manager will continue to hire candidates based on strong technical competencies, they also need to consider other traits such as transformational leadership skills and emotional intelligence as well. Information technology sector's project managers with competencies such as attentiveness, communication, managing conflict, and teamwork are very important for the project because these competencies are significantly related to the project success. In addition, emotionally intelligent project managers are vital in any new venture due to the competitive nature of most organizations. Research shows that PM's with requisite competencies along with high EQ and TL will provide more advantages to organizations and projects than those who 
A. Afzal, M.M.Khan, B. G. Mujtaba. The Impact of Project Managers' Competencies, Emotional Intelligence and Transformational Leadership on Project Success in the Information Technology Sector

lack them. Additionally, we can say that for Information Technology project managers, independent variables like project manager's competencies, emotional intelligence and transformational leadership can be designated as indicators of boosting up performance. Therefore, we can conclude that, to achieve success in projects and organizations and to maintain a good environment at the workplace, there is a need for project managers with a wide range of competencies, a very high emotional quotient, and transformational leadership skills.

This research has been done on the IT sector to check the impact of project managers' competencies, emotional intelligence and transformational leadership on a project's success. Based on the results, we recommend that the IT sector appoint project managers who have competencies like communication, teamwork, attentiveness, conflict management, and have efficiency in management skills. Likewise, they need to help nurture their IT personnel, while boosting their competencies, emotional intelligence and transformational leadership skills through workshops and seminars.

The research was conducted in twin cities due to limited resources and time. The time horizon of the study was cross-sectional. The sample size was 250 because the research data was collected from software houses, which were convenient in the region. The study is carried out in the IT sector, therefore generalization to other sectors (i.e., education, industrial sector, telecommunication, multinational firms) may not be possible. This study is also limited to the personal perception of project managers.

Directions for Future Research. The cross-sectional study was used in a sense that the study has been conferred within a speculated time frame in a specific area. We were not able to go for the longitudinal way of designing and organizing the sample as time was very limited and financial implications were present. In the future, the longitudinal way of organizing the sample should be implemented as it might better authenticate the study.

The study's model can be used for other sectors like education, telecommunication, banking, etc., to evaluate the precise relationship between project managers and project success. Also, in the future, researchers can add mediators or moderators to check their impact on dependent and independent variables in various industries. We cannot expect the same results for other sectors in accordance to the ones observed for the IT sector.

The questionnaire was in English which is not the first language of a majority of these project managers who took part in the research. So future questionnaires should be translated in Urdu or other local languages which are spoken and fully understood by the project managers. This will ensure that the results are more accurate and a better opinion can be formulated.

The research was centred in the twin cities of Rawalpindi and Islamabad, whereas, the rest of the areas also have numerous software houses. It is recommended that this study should be replicated in other big cities where a huge number of software houses are located.

Conclusion. This research has been conducted on the information technology sector with project managers to check the impact and relationship of PMC's, EQ and TL on PS. The results supported that all the variables studied have a direct and positive influence on the project's success (PS).

IT project managers with competencies such as attentiveness toward others, effective communication, conflict management, and teamwork, can perform better and thrive in any environment. Efficient project managers prevent disruptions by strategizing and communicating with relevant individuals, such as key personnel and stakeholders. These project managers have the ability to lead a team and be an example for others. Project managers who have the ability to solve problems and manage conflict can save their people, teams and organizations from a big loss in a timely and friendly manner; thereby having a positive impact on the project success.

This study supports the theoretical argument that a project manager with a transformational leadership style has a positive impact on the project's success. IT project managers ranked transformational leadership as an important aspect for project success. Transformational leaders are inspiring and 
encouraging, stick to their teams, motivate employees, show them a correct path, and boost employees' confidence. As a result, a responsive and pleasant environment will be created in which the whole team works together under a trustworthy project manager and attain the project goals. Transformational leaders must ensure that there is no communication barrier between the higher and lower level ranked personnel, as the project manager is expected to better understand their own emotions and those of others.

This research linked and highlighted the importance of project managers' competencies, emotional intelligence and transformational leadership together with its impact on the project's success. Also, we encourage top management to hire ideal project managers' who can ensure that their organization's reputation rises and can utilize their technical and managerial skills towards making all projects a success.

Aga, D. A., Noorderhaven, N., \& Vallejo, B. (2016a). Transformational leadership and project success: The mediating role of team-building. International Journal of Project Management, 34(5), 806-818. https://doi.org/10.1016/j.jproman.2016.02.012

Alam, M., Gale, A., Brown, M. \& Khan, A. I. (2010b). The importance of human skills in project management professional development. International Journal of Managing Projects in Business, 3(3), 495-516. https://doi.org/10.1108/17538371011056101

Andrei, F., Smith, M. M., Surcinelli, P., Baldaro, B., \& Saklofske, D. H. (2016). The Trait Emotional Intelligence Questionnaire: Internal Structure, Convergent, Criterion, and Incremental Validity in an Italian Sample. Measurement and Evaluation in Counseling and Development, 49(1), 34-45. https://doi.org/10.1177/0748175615596786

Ashkanasy, N. M., Haertel, C. E. J., \& Zerbe, W. J. (2000). Emotions in the workplace: Research, theory, and practice. Emotions in the Workplace: Research, Theory, and Practice, 3-18. https://doi.org/10.2307/3094814

Avolio, B. J., \& Yammarino, F. J. (2013). Transformational and Charismatic Leadership: 10th Anniversary Edition: the Road Ahead. Monographs in Leadership and Management. https://doi.org/10.1108/S1479-3571(2013)0000005006

Awamleh, R., Gardner, W. L., \& Gardner, W. (1987). Perceptions of Leader Charisma and Effectiveness: the Effects of Vision Content, Delivery, and Organizational Performance. Bass \& Avolio, 10(3), 345-373.

Bass, B. M., \& Riggio, R. E. (2006). Transformational leadership (2nd ed.). Transformational Leadership (2nd Ed.), 282.

Brière, S., Proulx, D., Flores, O. N., \& Laporte, M. (2015). Competencies of project managers in international NGOs: Perceptions of practitioners. International Journal of Project Management, 33(1), 116-125.

Brown, S. L., \& Eisenhardt, K. M. (1995). Product Development: Past Research, Present Findings, and Future Directions. Academy of Management Review, 20(2), 343-378. https://doi.org/10.5465/AMR.1995.9507312922

Burke, C. S., Stagl, K. C., Klein, C., Goodwin, G. F., Salas, E., \& Halpin, S. M. (2006). What type of leadership behaviours are functional in teams? A meta-analysis. Leadership Quarterly, 17(3), 288-307. https://doi.org/10.1016/j.leaqua.2006.02.007

Cartwright, C., \& Yinger, M. (2007). Project Management Competency Development Framework, $2^{\text {nd }}$ Edition. PMI Global Congress 2007. Budapest, Hungary.

Clarke, N. (2010a). Emotional Intelligence and Its Leadership and Key Project Manager Competences. Project Management Journal, 41(2), 5-20. https://doi.org/10.1002/pmj

Clarke, N. (2010b). Emotional intelligence and its relationship to transformational leadership and key project manager competences. Project Management Journal, 41(2), 5-20. https://doi.org/10.1002/pmj.20162

Conger, J. A. (1999). Charismatic and transformational leadership in organizations: An insider's perspective on these developing streams of research 27. Leadership Quarterly, 10(2), 145-179.

Crawford, L. (2005). Senior management perceptions of project management competence. International Journal of Project Management, 23(1), 7-16. https://doi.org/10.1016/j.jproman.2004.06.005

Creasy, T., \& Anantatmula, V. S. (2013). From every direction - How personality traits and dimensions of project managers can conceptually affect project success. Project Management Journal. https://doi.org/10.1002/pmj.21372

Davis, K. (2014). Different stakeholder groups and their perceptions of project success. International Journal of Project Management, 32(2), 189-201. https://doi.org/10.1016/j.jproman.2013.02.006

Davis, S. A. (2011). Investigating the impact of project managers' emotional intelligence on their interpersonal competence. Project Management Journal, 42(4), 37-57. https://doi.org/10.1002/pmj.20247

Dubinsky, A., Yammarino, F., Jolson, M., \& Spangler, W. (1995). Transformational leadership: an initial investigation in sales management. Journal of Personal Selling and Sales Management, 15, 17-29.

Ekrot, B., Kock, A., \& Gemünden, H. G. (2016). Retaining project management competence - Antecedents and consequences. International Journal of Project Management, 34(2), 145-157. https://doi.org/10.1016/j.jproman.2015.10.010

El-Sabaa, S. (2000). The skills and career path of an effective project manager. International Journal of Project Management, $19,1-7$.

Fink, A. (1995). How to Report on Surveys. The Survey Kit. https://doi.org/10.4135/9781412984461

Frey, L. R., Botan, C. H., \& Kreps, G. L. (2000). Textual analysis. Investigating Communication: An Introduction to Research Methods, 514. Retrieved from http://books.google.com/books?id=4pThAAAAMAAJ\&pgis=1

Gardner, L., \& Stough, C. (2002). Examining the relationship between leadership and emotional intelligence in senior-level

http://mmi.fem.sumdu.edu.ua/en 
A. Afzal, M. M. Khan, B. G. Mujtaba. The Impact of Project Managers' Competencies, Emotional Intelligence and Transformational Leadership on Project Success in the Information Technology Sector

managers. Leadership \& Organization Development Journal, 23(2), 68-78. https://doi.org/10.1108/01437730210419198

Geoghegan, L., \& Dulewicz, V. (2008). Do project managers leadership competencies contribute to project success? Project Management Journal, 39(4), 58-67. https://doi.org/10.1002/pmj.20084

Gillard, S., \& Price, J. (2005). The competencies of effective project managers: A conceptual analysis. International Journal of Management, (March 2005), $\quad 48-54 . \quad$ Retrieved from http://scholar.google.com/scholar?hl=en\&btnG=Search\&q=intitle:The+Competencies+of+Effective+Project+Managers+:+A+Conce ptual+Analysis\#0

Gladden, R. R. (2007). PROJECT MANAGEMENT: STRATEGIC DESIGN AND IMPLEMENTATION, 5TH EDITION. Project $\begin{array}{lllll}\text { Management } \quad 38(1), & 124 . & \text { Retrieved } & \text { from } & \mathrm{http}: / / 0\end{array}$ search.ebscohost.com.brum.beds.ac.uk/login.aspx?direct=true\&db=buh\&AN=24844793\&site=ehost-live\&scope=site

Goleman, D. (1995). Emotional intelligence: Why it can matter more than IQ for the character, health and lifelong achievement. Bantam Books: https://doi.org/10.1016/S0962-1849(05)80058-7

Goleman, D., Boyatzis, R. E., \& McKee, A. (2002). Primal Leadership: Learning to Lead with Emotional Intelligence. Boston, Mass: Harvard Business Review Press, p. 306.

Gundersen, G., Hellesoy, B. T., \& Raeder, S. (2012). Leading International Project Teams: The Effectiveness of Transformational Leadership in Dynamic Work Environments. Journal of Leadership \& Organizational Studies, 19(1), 46-57. https://doi.org/10.1177/1548051811429573

Hauptfleisch, S., \& Uys, J. S. (2006). The experience of work in a call centre environment. Annual Review of Biochemistry, 32(2), 23-30. https://doi.org/10.1146/annurev-biochem-060408-172623

Henderson, L. S. (2008). The impact of the project manager's communication competencies. Project Management Journal, 39 , 48-59. https://doi.org/10.1002/pmj

Henry, G. T. (2009). Practical Sampling. The SAGE Handbook of Applied Social Research Methods, 77-105. https://doi.org/10.4135/9781412985451

Jiang, J. (2014). The Study of the Relationship between Leadership Style and Project Success. American Journal of Trade and Policy, 1(1), 51-55

Katz, R., \& Allen, T. J. (1985). Project Performance and the Locus of Influence in the R\&D Matrix. Academy of Management Journal, 28(1), 67-87. https://doi.org/10.2307/256062

Keegan, A. E., \& Den Hartog, D. N. (2004). Transformational leadership in a project-based environment: A comparative study of the leadership styles of project managers and line managers. International Journal of Project Management, 22(8), 609-617. https://doi.org/10.1016/j.jiproman.2004.05.005

Kissi, J., Dainty, A., \& Tuuli, M. (2013). Examining the role of transformational leadership of portfolio managers in project performance. International Journal of Project Management, 31(4), 485-497. https://doi.org/10.1016/j.jproman.2012.09.004

Lannon, J., Loufrani-Fedida, S., Missonier, S., Samset, K., Volden, G. H., Todorović, M. L., .. Stellingwerf, R. (2015). Project success analysis framework: A knowledge-based approach in project management. International Journal of Project Management 33(4), 772-783. https://doi.org/10.1016/j.ijproman.2014.10.009

Leybourne, S., \& Sadler-Smith, E. (2006). The role of intuition and improvisation in project management. International Journal of Project Management, 24(6), 483-492. https://doi.org/10.1016/j.jproman.2006.03.007

Lloyd-Walker, B., \& Walker, D. (2011). Authentic leadership for 21 st-century project delivery. International Journal of Project Management, 29(4), 383-395. https://doi.org/10.1016/j.jproman.2011.02.004

Lowe, K. B., Kroeck, K. G., \& Sivasubramaniam, N. (1996). Effectiveness correlates of transformational and transactional leadership: A meta-analytic review of the mlq literature. Leadership Quarterly, 7(3), 385-425. https://doi.org/10.1016/S10489843(96)90027-2

MacNealy, M. S. (1999). Empirical Research in the Humanities. In Strategies for Empirical Research in Writing (pp. 1-14)

Malinowski, M. F. (2012). Leadership principles for project success. Project Management Journal, 43(1), p. 91. Link: https://doi.org/10.1002/pmi.20289

Maqbool, R.; Sudong, Y.; Manzoor, N.; and Rashid, Y. (2017). The Impact of Emotional Intelligence, Project Managers' Competencies, and Transformational Leadership on Project Success An Empirical Perspective. Project Management Journal, 48(3), 58-75.

Miao, C., Humphrey, R. H., \& Qian, S. (2016). Leader emotional intelligence and subordinate job satisfaction: A meta-analysis of main, mediator, and moderator effects. Personality and Individual Differences, 102, 13-24. https://doi.org/10.1016/j.paid.2016.06.056

Miao, C., Humphrey, R. H., \& Qian, S. (2017). A meta-analysis of emotional intelligence effects on job satisfaction mediated by job resources, and a test of moderators. Personality and Individual Differences, 116, 281-288.

Mujtaba, B. G., Tajaddini, R. and Chen, L. Y. (2011). Business Ethics Perceptions of Public and Private Sector Iranians. Journal of Business Ethics, 104(3), 433-447.

Mujtaba, B. G. and Sims, R. (2011). Gender differences in managerial attitudes towards unearned privilege and favouritism in the retail sector. Employee Responsibilities and Rights Journal, 23(3), 205-217.

Müller, R., \& Rodney Turner, J. (2010). Attitudes and leadership competences for project success. Baltic Journal of Management, 5(3), 307-329. https://doi.org/10.1108/17465261011079730 
Muzio, E., Fisher, D. J., Thomas, E. R., \& Peters, V. (2007). Soft Skills Quantification (SSQ) For Project Manager Competencies. Project Management Journal, 38(2), 30-38.

Neuhauser, C. (2007). Project Manager Leadership Behaviors and Frequency of Use by Female Project Managers. Project Management Journal, 38, 21-31.

Obradovic, V., Jovanovic, P., Petrovic, D., Mihic, M., \& Mitrovic, Z. (2013). Project Managers' Emotional Intelligence - A Ticket to Success. Procedia - Social and Behavioral Sciences, 74, 274-284. https://doi.org/10.1016/j.sbspro.2013.03.034

Pant, I., \& Baroudi, B. (2008). Project management education: The human skills imperative. International Journal of Project Management, 26(2), 124-128. https://doi.org/10.1016/j.jproman.2007.05.010

Papke-Shields, K., Beise, C., \& Quan, J. (2010). Do project managers practice what they preach, and does it matter to project success? International Journal of Project Management, 28(7), 650-662.

Pelletier, R. A., \& Mujtaba, B. G. (2015). Maximizing Employee Happiness and Well-being: An Examination of Value Creation and Competitive Advantage at Zappos. Advances in Social Sciences Research Journal, 2(4), 220-232.

Pieterse, A. N., van Knippenberg, D., Schippers, M., \& Stam, D. (2010). Transformational and transactional leadership and innovative behavior: the moderating role of psychological empowerment. Journal of Organizational Behavior, 31(4), 609-623.

Ping, Han, Mujtaba, Bahaudin G., and Jieqiong, Cao (2012). Management Skills' Structure in Chinese Small and Medium-Sized Enterprise. SAM: Advanced Management Journal, 77(1), 13-21.

Pryke, S., Lunic, D., \& Badi, S. (2015). The effect of leader emotional intelligence on leader-follower chemistry: a study of construction project managers. Construction Management and Economics, 33(8), 603-624.

Rehman, R. R. (2011). Role of emotional intelligence on the relationship among leadership styles, decision making styles and organizational performance: A review. Interdisciplinary Journal of Contemporary Research in Business, 3(1), 409-416.

Rezvani, A., Chang, A., Wiewiora, A., Ashkanasy, N. M., Jordan, P. J., \& Zolin, R. (2016). Manager emotional intelligence and project success: The mediating role of job satisfaction and trust. International Journal of Project Management, 34(7), 1112-1122.

Shoaib, S. and Mujtaba, B. G. (2017). The Moral Hazards of Higher-Education Faculty: A Qualitative Study with an Agency Perspective. Advanced Management Journal, 82(2), 20-39.

Skulmoski, G. J., \& Hartman, F. T. (2010). Information systems project manager soft competencies: A project-phase investigation. Project Management Journal, 41(1), 61-80. https://doi.org/10.1002/pmj.20146

Sohmen, V. S. (2013). Leadership and Teamwork: Two Sides of the Same Coin. Journal of IT and Economic Development, 4(2), 1-18. https://doi.org/10.1007/s13398-014-0173-7.2

Stevenson, D. H., \& Starkweather, J. A. (2010). PM critical competency index: IT execs prefer soft skills. International Journal of Project Management, 28(7), 663-671. https://doi.org/10.1016/j.jproman.2009.11.008

Sumner, M., Bock, D., \& Giamartino, G. (2006). Exploring the linkage between the characteristics of it project leaders and project success. Information Systems Management, 23(4), 43-49.

Sunindijo, R. Y. (2015). Project manager skills for improving project performance. International Journal of Business Performance Management, 16(1), 67. https://doi.org/10.1504/IJBPM.2015.066041

Sunindijo, R. Y., Hadikusumo, B. H. W., \& Ogunlana, S. (2007). Emotional Intelligence and Leadership Styles in Construction Project Management. Journal of Management in Engineering, 23(4), 166-170.

Sy, T., Côté, S., \& Saavedra, R. (2005). The Contagious Leader: Impact of the Leader's Mood on the Mood of Group Members, Group Affective Tone, and Group Processes. Journal of Applied Psychology, 90(2), 295-305. https://doi.org/10.1037/0021 9010.90.2.295

Tajaddini, R. and Mujtaba, B. G. (2011). Stress and Leadership Tendencies of Respondents from Iran: Exploring Similarities and Differences based on Age and Gender. Public Organization Review, 11(3), 219-236. Website: http://www.springerlink.com/content/818m37x43u509781/

Turner, J. R., \& Müller, R. (2005). The project manager's leadership style as a success factor on projects: a literature review. Project Management Journal, 36, 49-61. 13p. 1 Diagram.

Vincent-Höper, S., Muser, C., \& Janneck, M. (2012). Transformational leadership, work engagement, and occupational success. Career Development International, 17(7), 663-682. https://doi.org/10.1108/13620431211283805

Vinhas Da Silva, R., \& Faridah Syed Alwi, S. (2006). Cognitive, affective attributes and conative, behavioural responses in retail corporate branding. Journal of Product \& Brand Management, 15(5), 293-305. https://doi.org/10.1108/10610420610685703

Whitney, K. M., \& Daniels, C. B. (2013). The root cause of failure in complex IT projects: Complexity itself. Procedia Computer Science, 20, 325-330. https://doi.org/10.1016/i.procs.2013.09.280

Yammarino, F. J., Spangler, W. D., \& Bass, B. M. (1993). Transformational Leadership and Performance: A Longitudinal Investigation. Leadership Quarterly, 4(1), 81-102. https://doi.org/10.1016/1048-9843(93)90005-E

Yang, L. R., Huang, C. F., \& Wu, K. S. (2011a). The association among project manager's leadership style, teamwork and project success. International Journal of Project Management, 29(3), 258-267. https://doi.org/10.1016/j.jproman.2010.03.006

Zareen, M., Razzaq, K. and Mujtaba, B. G. (December 2015). Impact of Transactional, Transformational and Laissez-Faire Leadership Styles on Motivation: A Quantitative Study of Banking Employees in Pakistan. Public Organization Review, 15(4), 431. 549 . 
A. Afzal, M. M. Khan, B. G. Mujtaba. The Impact of Project Managers' Competencies, Emotional Intelligence and Transformational Leadership on Project Success in the Information Technology Sector

А. Афзал, Університет КОМСАТС (Ісламабад, Пакистан);

M. М. Хан, доцент, Університет КОМСАТС (Ісламабад, Пакистан);

Б. Г. Муджата, професор, Ново Південно-Східний університет (Флоріда, США).

Вплив компетенцій проектного менеджеру, його емоційного інтелекту та трансформаційного лідерства на успіх проекту в галузі інформаційних технологій

Метою дослідження є вивчення впливу компетенцій проектного менеджеру (PMC), його емоційного інтелекту (EQ) та транссормаційного лідерства (TL) на успіх проекту у секторі інформаційних технологій (PS). У ході дослідження було опитано 250 респондентів, до складу яких входили: проектні менеджери, керівники та директори проектів, фуннкиіональні менеджери та ініціатори проекту, у тому числі, які працюють у секторі інформаційних технологій (IT). Результати аналізу показали, що основні характеристики проектного менеджеру позитивно впливають на успіх проекту. Автори дослідження пропонують під час прийняття рішень щодо прийняття на роботу працівника (проектного менеджеру, керівників та директорів проектів) брати до уваги їх комунікативні здібності, готовність до роботи в команді, ефекттивність управління конфрліктами, а також досвід роботи на управлінських посадах у сфері IT. Крім того, автори наголошують на необхідності інвестування в розвиток наявного персоналу та удосконалення їх компетенцій, емоційного інтелекту та транссормаційного лідерства через професійні курси, тренінги та семінари. Результати дослідження свідчать про позитивний взаємозв'язок між успіхом проекту та наявністю навичок трансформаційного лідерства у проектного менеджеру. Так, менеджери IT-проектів визначили трансформаційне лідерство як ключовий фактор їх успішності. Автори стверджують, що основне завдання транссрормаційних лідерів стимулювати, надихати, мотивувати працівників та підвищувати їх впевненість в успішності реалізації проекту та досягненні поставлених цілей. В результаті зазначених дій формується позитивний психологічний клімат команди, що реалізує IT-проект. 3 метою підвищення еффективності роботи команди IT-спеціалістів авторами було запропоновано ряд заходів щодо формування та реінжерінгу бізнес-процесів.

Ключові слова: компетенції, емоційний інтелект, трансформаційне лідерство, успіх проекту. 